Brazilian Journal of Microbiology (2009) 40: 685-692

ISSN 1517-8382

\title{
MOLECULAR EPIDEMIOLOGY OF SHIGELLA SPP STRAINS ISOLATED IN TWO DIFFERENT METROPOLITAM AREAS OF SOUTHEAST BRAZIL
}

\author{
Michelle Angelini ${ }^{1}$, Eliana Guedes Stehling ${ }^{1}$, Maria Luiza Moretti ${ }^{2}$, Wanderley Dias da Silveira ${ }^{1^{*}}$ \\ ${ }^{1}$ Departamento de Microbiologia e Imunologia, Instituto de Biologia, Universidade Estadual de Campinas, Campinas, São \\ Paulo, Brasil; ${ }^{2}$ Departamento de Clinica Médica, Faculdade de Ciências Médicas, Universidade Estadual de Campinas, \\ Campinas, São Paulo, Brasil
}

Submitted: August 25, 2008; Returned to authors for corrections: September 24, 2008; Approved: May 03, 2009.

\begin{abstract}
Shigella spp., the human pathogen responsible for shigellosis, is highly infectious even at low levels. The incidence rate of shigellosis varies with geographical distribution, location human development index, and age groups, being higher among children aged under 5 years. In Brazil, a few works indicate that shigellosis cases are underestimated, with $S$. flexneri and $S$. sonnei strains being the major agents responsible for the shigellosis cases. The present study used pulsed field gel electrophoresis (PFGE) to investigate the molecular epidemiology of 119 strains of $S$. sonnei and S. flexneri isolated from shigellosis cases that occurred in the metropolitan areas of Ribeirão Preto and Campinas Cities, São Paulo Sate, southeast Brazil. The results indicated (i) the existence of just a few strain clusters for both species, but with genotype variability with either a high speed of genetic change or constant introduction of several genotypes, considering the intense migration to these two metropolitan areas, and (ii) the prevalence of specific genotypes in each geographical area, which suggests the successful adaptation of some genotypes to the local environmental conditions. Our results indicate the need of more efficacious sanitary barriers to prevent Shigella spp. outbreaks and epidemics.
\end{abstract}

Key words: Shigella sonnei, Shigella flexneri, Epidemiology, Characterization, PFGE

\section{INTRODUCTION}

Shigella spp., the human pathogen responsible for shigellosis, is highly infectious, even at low counts (17). The clinical signs of shigellosis range from mild diarrhea to severe dysentery, with extra intestinal manifestations composed of fever, vomiting, abdominal discomfort, nausea, and neurological symptoms (headache, lethargy, confusion, nuchal rigidity or hallucinations). The worldwide annual

*Corresponding Author. Mailing address: Departamento de Microbiologia e Imunologia, UNICAMP, CP 6109, CEP 13083-970, Campinas, SP, Brasil.; Phone: +55 (19) 3521-6275, Fax +55 (19) 3521-6276.; E-mail: wds@unicamp.br 
incidence of shigelloses is approximately 164.7 million cases, with 163.2 million of the cases occurring in developing countries (6). The incidence rate varies according to age, geographical distribution, and local human development index (HDI). The isolation rate of Shigella spp. from diarrheagenic stools is higher among children under 5 years old (5), particularly in children younger than six months living in low HDI countries (14).

Traditionally, the Shigella genus is classified as being formed by four species. Shigelloses are caused by $S$. dysenteriae, S. flexneri, and S. sonnei, which are the species of major epidemiological interest (7). Among the pathogenic Shigella subgroups, S. flexneri is the most commonly detected strain (57\%) in infectious processes, followed by $S$. sonnei strains. S. sonnei strains tend to cause milder illness than $S$. flexneri, persist in both developed and developing countries and tend to cause sporadic diarrhea and occasional outbreaks in specific epidemiological niches, such as daycare centers, where personal hygiene may be suboptimal ( 8 , 14). In Brazil, a few studies $(4,9,11)$ indicate that shigellosis cases are underestimated, with S. flexneri and S. sonnei strains being the major pathogenic agents (11).

Molecular techniques, combined with traditional techniques, are used to differentiate species and strains $(2,10$, 12, 13) of pathogenic bacteria. Pulsed field gel electrophoresis (PFGE) is considered one of the most reliable, discriminatory, and reproducible typing method, allowing the detection of a high degree of DNA polymorphism (18) for epidemiological purposes $(15,18,19$, 21) and in routine typing of Shigella species (3).

In our study, PFGE was applied to the genotyping of 119 Shigella strains (61 S. flexneri and $58 \mathrm{~S}$. sonnei) isolated from shigellosis cases that had occurred in two metropolitan areas located $250 \mathrm{~km}$ apart (Campinas and Ribeirão Preto Cities, São Paulo State, southeast Brazil). The purpose of the study was to analyze the genetic relationship among strains and to determine the geographically predominant clones, if any.

\section{MATERIAL and METHODS}

\section{Bacterial Strains}

From 1999 to 2000, 59 Shigella strains (31 S. flexneri and $28 \mathrm{~S}$. sonnei) were isolated from stool samples of different patients assisted at the São Paulo State University Hospital in Ribeirão Preto (FMRP-USP). From 1987 to 2001, 60 strains (30 S. flexneri and $30 \mathrm{~S}$. sonnei) were isolated from stool samples of different patients residing in metropolitan Campinas (12) by Adolfo Lutz Institute. The isolates were stored at $-70{ }^{\circ} \mathrm{C}$ in Luria Bertani (LB) medium (16) with $15 \%$ glycerol and grown in LB medium $\left(37^{\circ} \mathrm{C}\right.$; $\left.18-24 \mathrm{~h}\right)$ for routine assays.

\section{PFGE}

For genomic DNA extraction, strains were grown overnight in LB medium at $37^{\circ} \mathrm{C}$ and total DNA extracted as described by Ausubel et al. (1). The PFGE procedure was performed as described by Yatsuyanagi et al. (20), with some modifications. Briefly, $2 \mathrm{~mL}$ of culture containing $10^{9}$ colony-forming units $(\mathrm{CFU}) / \mathrm{mL}$ was harvested, suspended in a suspension buffer $(100 \mathrm{mM} \mathrm{pH} 7.2$ Tris, $20 \mathrm{mM} \mathrm{NaCl}, 100$ $\mathrm{mM}$ EDTA), mixed with an equal volume of $2 \%$ lowmelting-point agarose (GIBCO BRL, Grand Island, N.Y. 14072 USA), dispensed in a plug mold (Bio Rad Laboratories), and allowed to solidify. For lysis, the plugs were incubated for $2 \mathrm{~h}$ at $37^{\circ} \mathrm{C}$ in the cell suspension buffer with $1 \mathrm{mg} / \mathrm{mL}$ of lysozyme (Sigma-Aldrich CO. Box 14508, St. Louis, MO 63178 USA). The plugs were washed with sterilized-distillated water and incubated overnight at $50^{\circ} \mathrm{C}$ in a protein removing buffer $(0.25 \mathrm{M} \mathrm{pH} 9$ EDTA, $0.5 \%$ sarcosil, $0.5 \mathrm{mg} / \mathrm{mL}$ proteinase $\mathrm{K}$ ) and washed 4 times for 30 min in TE buffer (10mM pH 8 Tris-HCl, 1 mM EDTA) 
afterwards. One plug was washed for $1 \mathrm{~h}$ with $300 \mu \mathrm{L}$ of the enzyme buffer and incubated overnight at $37^{\circ} \mathrm{C}$ with $20 \mathrm{U}$ of $\mathrm{XbaI}$ in the reaction conditions recommended by the manufacturer (Pharmacia LKB Biotechnology AB, Uppsala, Sweden). A plug slice was washed for $30 \mathrm{~min}$ in TE buffer, loaded into a well of $1 \%$ Ultra Pure ${ }^{\mathrm{TM}}$ Agarose gel (Invitrogen, Auckland 1135, New Zealand) in 0.5X TBE (Tris-Borate EDTA) buffer. Electrophoresis was performed in $0.5 \mathrm{X}$ TBE buffer at $14^{\circ} \mathrm{C}$ for $22 \mathrm{~h}$ using a CHEF DR-III apparatus (Bio-Rad, 2000 Alfred Nobel Drive Hercules, CA94547, USA) with an electric field of $6 \mathrm{~V} / \mathrm{cm}$ and pulse time from 5 to $35 \mathrm{~s}$. A lambda ladder (New England Biolabs) was used as a molecular size marker. The PFGE banding patterns were fingerprinted and clustered using GelCompar II software (version 2.0, Applied Maths, Saint-Martens-Latem, Belgium). The similarity dendrogram was obtained using the Dice similarity index by the unweighted pair group method with arithmetic averages (UPGMA) using 1\% tolerance coefficient.

\section{RESULTS}

The genotypes obtained by PFGE were analyzed separately according to Shigella species S. sonnei (Figure 1) and S. flexneri (Figure 2). A similarity dendrogram was constructed for each species.

$S$. sonnei genotypes resulted in a dendrogram constituted by two main clusters (A and B; Figure 1), both with less than $35 \%$ similarity and strains with bands that had molecular weights between $580 \mathrm{~Kb}$ and $25 \mathrm{~Kb}$, with an average of 14 bands for cluster A2 and 18 for cluster B1. Cluster A presented two strain subgroups (A1 and A2), with 20 (34.5\%) and $10(17.2 \%)$ strains, respectively. Subgroup A1 was composed of $15(25.8 \%)$ and $5(8.6 \%)$ of strains isolated in the metropolitan areas of Campinas and Ribeirão Preto, respectively. Subgroup A2 was composed of 10 (17.2\%) strains, all isolated in Ribeirão Preto. Cluster $\mathrm{B}$ also presented two strain subgroups (B1 and B2), with 16 (27.6\%) and $12(20.6 \%)$ strains, respectively. In subgroup B1, most of the strains $(13 ; 22.4 \%)$ were isolated in Campinas, while only 3 strains were isolated in Ribeirão Preto. Subgroup B2 was composed of $10(17.2 \%)$ strains isolated in Ribeirão Preto and 2 strains isolated in Campinas.

The analysis of the $S$. flexneri genotypes resulted in a dendrogram constituted by two main clusters (C and D; Figure 2) with less than $40 \%$ similarity and strains with bands with molecular weights between $560 \mathrm{Kbp}$ and $30 \mathrm{Kbp}$, with an average of 17 bands for cluster $\mathrm{C} 2$ and 18 for cluster $\mathrm{C} 3$. Cluster D had $7(11.5 \%)$ strains, all isolated in Ribeirão Preto. Cluster C included most of the strains $(54 ; 88.5 \%)$ and comprised strains from both metropolitan areas. Cluster C had three strain subgroups $(\mathrm{C} 1, \mathrm{C} 2$, and $\mathrm{C} 3)$, with subgroup similarity ranging from $40 \%$ to $45 \%$. Subgroup C1 contained $13(21.3 \%)$ strains with $8(13.1 \%)$ and $5(8.2 \%)$ strains isolated in Ribeirão Preto and Campinas, respectively. Subgroup C2 contained 31 (51\%) strains with 7 (11.5\%) strains isolated in Ribeirão Preto and 24 (39.4\%) in Campinas. Subgroup C3 contained 10 strains (16.5\%) with 9 (14.75\%) strains isolated in Ribeirão Preto.

\section{DISCUSSION}

This work analyzed 119 Shigella spp strains isolated from shigellosis cases that occurred in two major metropolitan areas located $250 \mathrm{~km}$ apart in southeast Brazil. These two areas are important industrial, technological, and agricultural regions, tourism, educational and business destinations and migration poles of workers and students from other regions of Brazil. Despite their economic importance, these metropolitan areas have different HDI and 
Angeline, M. et al.

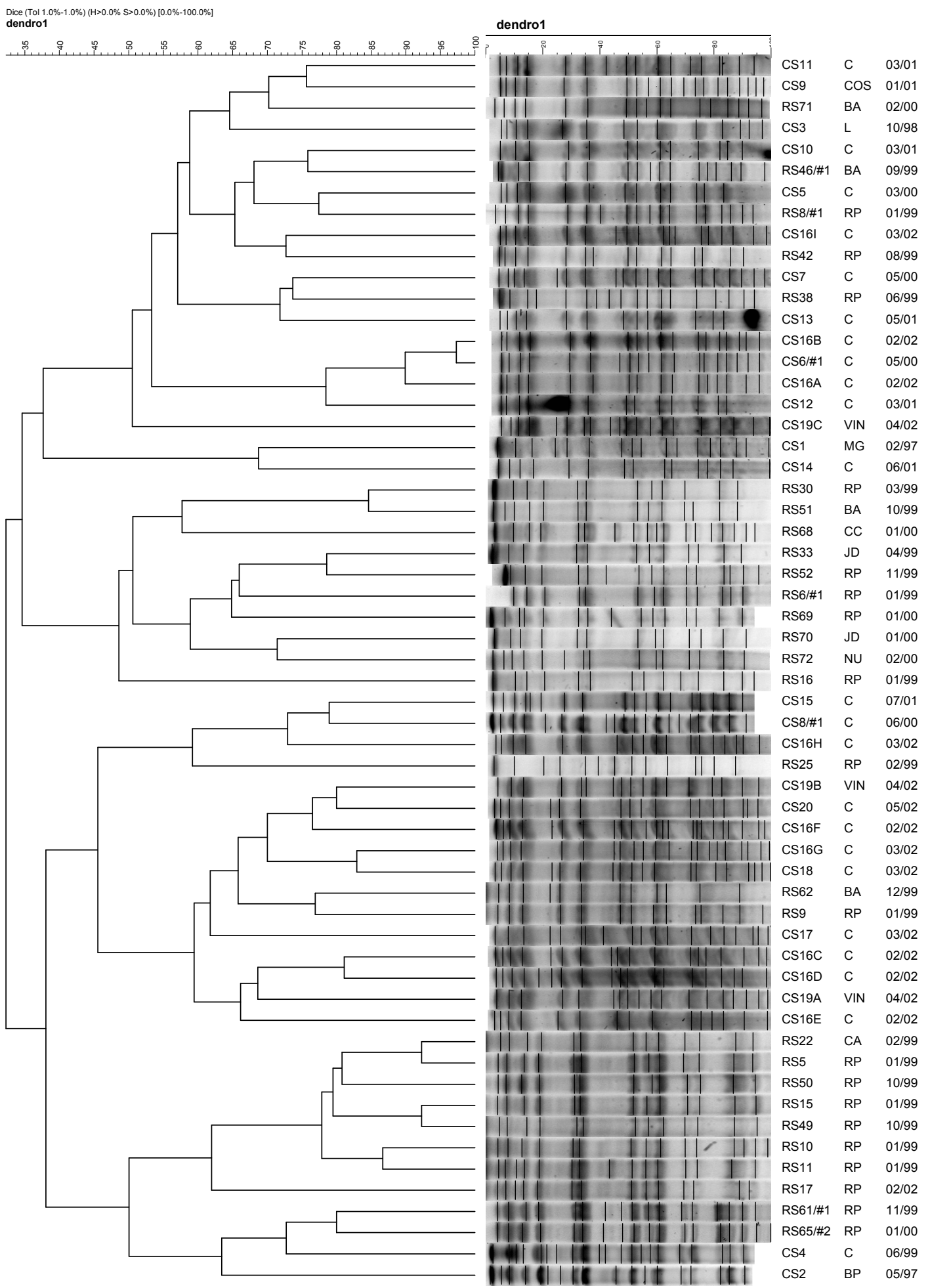


Figure 1. Similarity dendrogram of fingerprinting patterns obtained for S. sonnei strains isolated in Campinas (CS) and Ribeirão Preto (RS) metropolitan regions. The two clusters were designated as $\mathrm{A}$ and $\mathrm{B}$ and divided into two subgroups (A1 and $\mathrm{A} 2$, and $\mathrm{B} 1$ and $\mathrm{B} 2$, respectively). The name of the strains are followed by the site* abbreviation and the isolation date. The Ribeirão Preto strains were isolated in Jardinópolis (JD), Barrinha (BA), Cambirá (CA), Cássia dos Coqueiros (CC), Nuporanga (NU), and Ribeirão Preto (RP). The Campinas region strains were isolated in Campinas (C), Mogi Guaçú (MG), Bragança Paulista (BP), Limeira (L), Cosmópolis (COS), and Vinhedo (VIN).

have slums, which favor the spread of infectious illnesses. The study and characterization of the genotypes of pathogenic agents that cause potentially fatal diseases, such as shigellosis, would help to track these agents during outbreaks and epidemics and determine better control and eradication measures.

The results herein obtained indicate the existence of two main groups of genetic similarity between the $S$. sonnei and the $S$. flexneri strains isolated in both areas. These two groups were constituted by strains isolated in both metropolitan areas, as happened for most strains, or in just one metropolitan area, such as subgroup A2 of S. sonnei and group D of S. flexneri, whose strains were all isolated in metropolitan Ribeirão Preto.

The strains of $S$. sonnei from the Campinas region were majority in group A1 and group B1 while the strains from Ribeirão Preto region were majority in the groups A2 and B2 indicating that although being from different regions, there is a genetic similarity between strains in each strains group and the predominance of closely related genotypes in specific geographical regions. These data are also corroborated by the findings in the $S$. flexneri dendrogram where group $\mathrm{C} 1$ is mainly composed by strains isolated in Ribeirão Preto region, the group $\mathrm{C} 2$ is mainly composed by strains from Campinas region and group C3 is mainly composed by strains (90\%) isolated in the Ribeirão Preto region, agreeing with a previous study accomplished in towns located in the metropolitan Campinas area (12).

In the $S$. sonnei dendrogram the cluster A2 is composed only by strains isolated in the years of 1999 and 2000 with the group B1 being composed only by strains isolated after the year of 1999. In the dendrogram of S. flexneri, all strains of group C3, but strain CF24 that was isolated in the region of Campinas in the year of 2001, were isolated in 1999 in the region of Ribeirão Preto. In group D the majority (85.7\%) of the strains were isolated in 1999. These data, similarly to those observed in the previous paragraph indicate that specific strains with related geneotypes are responsible for causing the disease outbreaks.

Also, it is possible to observe that $77.5 \%$ of the shigelosis cases caused by S. sonnei and $71.7 \%$ of those caused by $S$. flexneri affect children under 6 years old, confirming previous works that show that these are infectious processes that attack mainly very young malnourishedchildren (5). In Brazil, a few works indicate that shigellosis cases are underestimated, since is not considered a compulsory notifiable disease (11).

The isolation dates of all the strains indicate that most of the cases occurred during the summer, i.e, the rain season, strengthening the hypothesis that the probable existance of the lack of basic sanitation condictions together with the excess of contaminated floodwater would facilitate the transmission of pathogens (14).

In conclusion, the existence of just a few Shigella strain clusters for both species with genotypic variability in the two studied areas could be explained either by the constant 
Angeline, M. et al.

Dice (Tol 1.0\%-1. $0 \%)$ (H>0.0\% S>0.0\%) $[0.0 \%-100.0 \%$
dendro1

dendro1

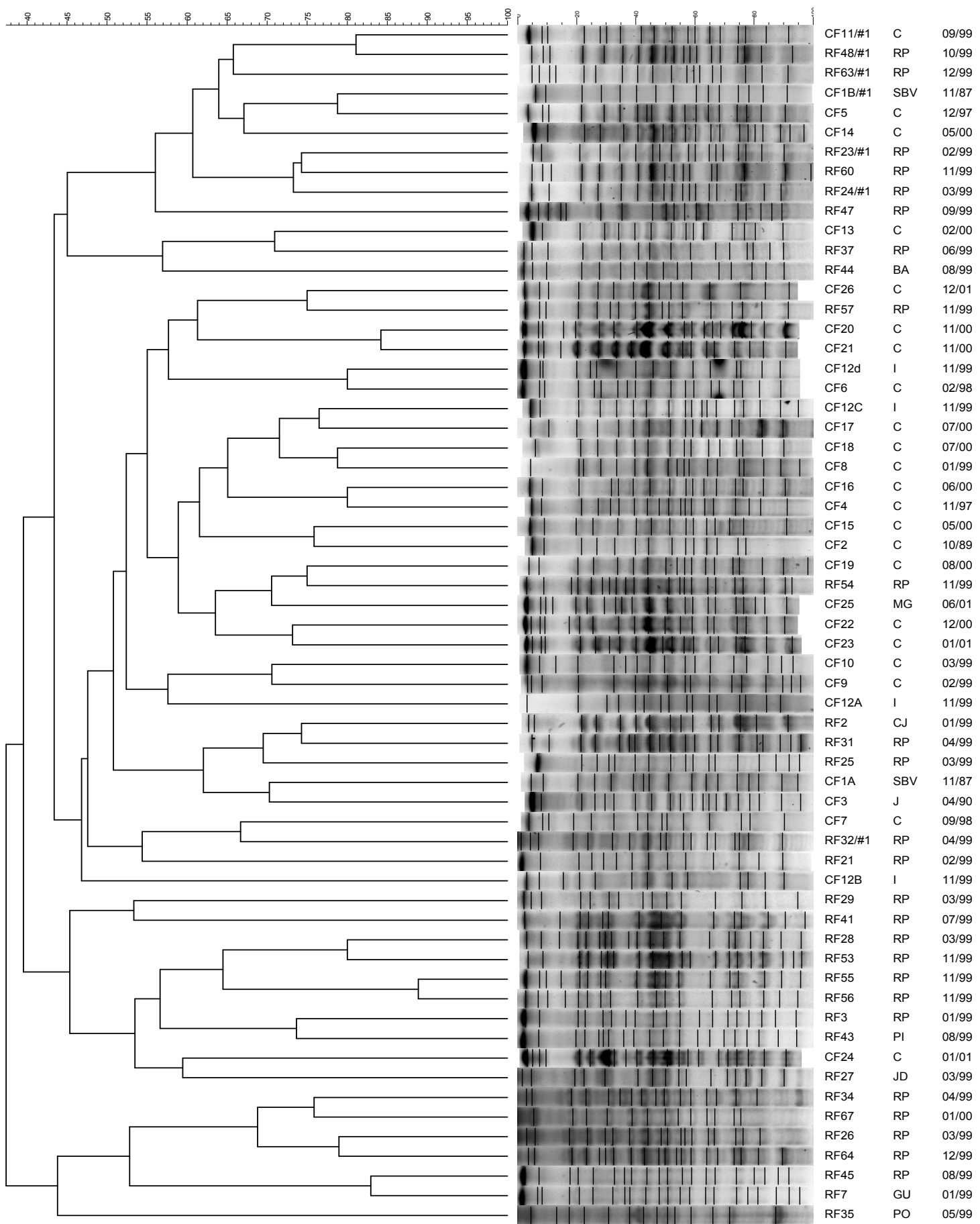


Figure 2. Similarity dendrogram of the fingerprinting patterns obtained for $S$. flexneri strains isolated in the Campinas (CF) and Ribeirão Preto (RF) metropolitan regions. The two clusters were designated as $\mathrm{C}$ and $\mathrm{D}$. Cluster $\mathrm{C}$ was divided into tree subgroups ( $\mathrm{C} 1, \mathrm{C} 2$, and $\mathrm{C} 3)$. The names of the strains are followed by the site abbreviation and isolation date. The Ribeirão Preto region strains were isolated in Cajurú (CJ), Guatapará (GU), Jardinópolis (JD), Pontal (PO), Pitangueiras (PI), Barrinha (BA), and Ribeirão Preto (RP). The Campinas region strains were isolated in São João da Boa Vista (SBV), Campinas (C), Jundiaí (J), Itapira (I), and Mogi Guaçú (MG).

introduction of new genotypes, considering the intense migration to these two regions, or a high rate of genetic change and the prevalence of specific genotypes in each geographical area. This might suggest that some genotypes have adapted to the local environmental conditions successfully.

Our findings urge health officers to take measures for more efficacious sanitary barriers to prevent shigellosis outbreaks and epidemics.

\section{ACKNOWLEDGMENTS}

This work was supported by grant No. 05/60928-0 from FAPESP (Fundação de Amparo à Pesquisa do Estado de São Paulo) and by a grant from PRPG (Pró-Reitoria de PósGraduação) UNICAMP. The authors thank Instituto Adolfo Lutz, São Paulo and Prof. Marcelo Brocchi for donating some strains.

\section{EPIDEMIOLOGIA MOLECULAR DE LINHAGENS \\ DE SHIGELLA SPP ISOLADAS EM DIFERENTES AREAS METROPOLITANAS DO SUDESTE DO BRASIL}

Shigella spp., o patógeno humano responsável pela shiguelose, apresenta grande poder infeccioso, mesmo em pequenas doses. A incidência de shiguelose varia de acordo com a distribuição geográfica, o índice de desenvolvimento humano local e a faixa de idade, sendo alto entre crianças com menos de 5 anos de idade. No Brasil, alguns trabalhos indicam que os casos de shiguelose são subnotificados sendo, $S$. flexneri e $S$. sonnei os principais agentes responsáveis pelos casos ocorridos. O presente estudo usou a técnica de eletroforese em campo pulsado (PFGE) para investigar a epidemiologia molecular de 119 linhagens de $S$. flexneri e $S$. sonnei, isoladas de casos de shiguelose que ocorreram nas regiões metropolitanas das cidades de Ribeirão Preto e Campinas, estado de São Paulo, na região Sudeste do Brasil. Os resultados indicam (i) a existência de apenas alguns grupos clonais para ambas as espécies, mas com variabilidade de genótipos indicando ou um alto índice de variação genética, ou a constante introdução de vários genótipos, considerando o movimento migratório intenso de pessoas nestas duas áreas metropolitanas, e (ii) a prevalência de genótipos específicos em cada área geográfica, o que sugere a existência de genótipos com maior capacidade de adaptação às condições ambientais locais. Os resultados indicam a necessidade de barreiras sanitárias mais eficientes para prevenir surtos e epidemias de Shigella spp.

Palavras Chave: Shigella sonnei, Shigella flexneri, Epidemiologia, Caracterização, PFGE.

\section{RESUMO}


Angeline, M. et al.

\section{REFERENCES}

1. Ausubel, F.M.; Brent, R.; Kingston, R.E.; Moore, D.D.; Smith, J.A.; Seidman, J.G.; Struhl, K. (1998). Current Protocols in Molecular Biology. New York: Green Publishing Associates; 1.6.1p.

2. Brenner, D.J.; Fanning, G.R.; Skeman, F.J.; Falkow, S. (1972). Polynucleotide sequence divergence among strains of Escherichia coli and closely related organisms. J. Bacteriol., 109: 953- 965.

3. DeLappe, N.; O’Halloran, F.; Fanning, S.; Corbett-Feeney, G.; Cheasty, T.; Cormican, M. (2003). Antimicrobial resistance and genetic diversity of Shigella sonnei isolates from western Ireland, an area of low incidence of infection. J. Clin. Microbiol., 41: 1919-1924.

4. Diniz-Santos, D.R.; Santana, J.S.; Barreto, J.R.; Andrade, M.G.; Silva, L.R. (2005). Epidemiological and microbiological aspects of acute bacterial diarrhea in children from Salvador, Bahia, Brazil. Braz. J. Infect. Dis., 9:77-83.

5. Ferreccio, C.; Prado, V.; Ojeda, A.; Cayyazo, M.; Abrego, P.; Guers, L.; Levine, M.M. (1991). Epidemiologic patterns of acute diarrhea and endemic Shigella infections in a poor periurban setting in Santiago, Chile. Am. J. Epidemiol., 134: 614-627.

6. Kotloff, K.L.; Winickoff, J.P.; Ivanoff, B.; Clemens, J.D.; Swerdlow, D.L.; Sansonetti, P.J.; Adak, G.K.; Levine, M.M. (1999). Global burden of Shigella infections: implications for vaccine development and implementation of control strategies. Bull. World Health Organ, 77: 651-666.

7. Levine, M.M. (2000). Immunization against bacterial diseases of the intestine. J. Pediatr. Gastroenterol. Nutr., 31:336-355.

8. Levine, M.M.; Kotloff, K.L.; Barry, E.M.; Pasetti, M.F.; Sztein, M.B. (2007). Clinical trials of Shigella vaccines: two steps forward and one step back on a long, hard road. Nat. Rev. Microbiol., 5:540-553.

9. Melo, M.C.N.; Taddei, J.A.A.C.; Diniz-Santos, D.R.; May, D.S.; Carneiro, N.B.; Silva, L.R. (2007). Incidence of diarrhea: poor parental recall ability. Braz. J. Infect. Dis., 11:571-579.

10. Ochman, H.; Whittam, T.S.; Caugant, D.A.; Selander, R.K. (1983). Enzyme polymorphism and genetic population structure in Escherichia coli and Shigella. J. Gen. Microbiol., 129: 2715-2726.

11. Peirano, G.; Souza, F.S.; Rodrigues, D.P. (2006). Frequency of serovars and antimicrobial resistance in Shigella spp. from Brazil. Men. Inst. Oswaldo Cruz, 101: 245-250.
12. Penatti, M.P.A.; Hollanda, L.M.; Nakazato, G.; Campos, T.A.; Lancellotti, M.; Angelini, M.; Brocchi, M.; Rocha, M.M.; Dias da Silveira, W. (2007). Epidemiological characterization of resistance and PCR typing of Shigella flexneri and Shigella sonnei strains isolated from bacillary dysentery cases in southeast Brazil. Braz. J. Med. Biol. Res., 40: 249-58.

13. Pupo, G.M.; Karaolis, D.K.; Lan, R.; Reeves, P.R. (1997). Evolutionary relationships among pathogenic and nonpathogenic Escherichia coli strains inferred from multilocus enzyme electrophoresis and $m d h$ sequence studies. Infect. Immun., 65: 2685-2692.

14. Ram, P.K.; Crump, J.A.; Gupta, S.K.; Miller, M.A.; Mintz, E.D. Part II (2008). Analysis of data gaps pertaining to Shigella infections in low and medium human development index countries, 1984-2005. Epidemiol. Infect., 136: 577-603.

15. Régua-Mangia, A.H.; Gomes, T.A.T.; Andrade, J.R.C.; Vieira, M.A.M.; Gonzalez, A.G.M.; Zahner, V.; Irinos, K.; Teixeira, L.M. (2003). Genetic Analysis of Escherichia coli strains carrying enteropathogenic Escherichia coli (EPEC) markers, isolated from children in Rio de Janeiro city, Brazil. Braz. J. Microbiol., 34: 38-41.

16. Sambrook, J.; Fritsch, E.F.; Maniatis, T. (1989). Molecular cloning: a laboratory manual. $2^{\text {nd }}$ edn. New York: Cold Spring Harbor Laboratory Press.

17. Small, P.; Blankenhorn, D.; Welty, D. (1994). Zinser, E.; Slonczewki, J.L. Acid and base resistance in Escherichia coli and Shigella flexneri: role of rpoS and growth pH. J. Bacteriol., 176:1729-1737.

18. Straden, A.; Frei, R.; Widmer, A.F. (2003). Molecular typing of methicillin-resistant Staphylococcus aureus: can PCR replace pulsedfield gel electrophoresis? J. Clin. Microbiol., 41: 3181-3186.

19. Wei, H.L.; Wang, Y.W.; Li, C.C.; Tung, S.K.; Chiou, C.S. (2007). Epidemiology and evolution of genotype and antimicrobial resistance of an imported Shigella sonnei clone circulating in central Taiwan. Diagn. Microbiol. Infect. Dis., 58: 469-475.

20. Yatsuyanagi, J.; Saito, S.; Sato, H.; Miyajima, Y.; Amano, K.I.; Enomoto, K. (2002). Characterization of enteropathogenic and enteroaggregative Escherichia coli isolated from diarrheal outbreaks. $J$. Clin. Microbiol., 40: 294-297.

21. Zhang, W.; Pan, J.C.; Meng, D.M.; Ye, R.; Wang, H.Q. (2007). PFGE of Shigella flexneri $4 \mathrm{c}$ isolates from food-poisoning outbreaks and sporadic diarrhea patients. Zhonghua Yu. Fang. Yi. Xue. Za. Zhi., 41: $50-53$. 